\title{
Physio-metabolic response of rainbow trout during prolonged food deprivation before slaughter
}

\author{
Rubén Bermejo-Poza \& Montserrat Fernández-Muela \& Jesús De la Fuente \& \\ Concepción Pérez \& Elisabet González de Chavarri \& María Teresa Díaz \& \\ Fernando Torrent \& Morris Villarroel
}

\begin{abstract}
Fish normally undergo periods of food deprivation that are longer than non-hibernating mammals. In aquacultured rainbow trout (Oncorhynchus mykiss), it is unclear how fasting may affect their physiological adaptative response, especially when they are normally fed daily. In addition, that response may vary with temperature, making it necessary to express fasting duration in terms of degree days. In the current study, trout were fasted for 5, 10, and 20 days $(55,107$, and 200 degree days $\left({ }^{\circ} \mathrm{C} \mathrm{d}\right)$, respectively). To assess the physiological response of fish to fasting, different
\end{abstract}

biometric, blood, plasma, and metabolic parameters were measured, as well as liver fatty acid composition. The fish weight, condition factor, and the hepatosomatic index of 5-day fasted trout were not significantly different from those of control fish. Gastric $\mathrm{pH}$ increased as fasting progressed while plasma concentrations of glucose, triglycerides, and total proteins decreased significantly after 10 days of fasting, while the percentage of non-esterified fatty acids increased. There were no significant differences in plasma ions (sodium, potassium, and calcium), except for chloride ion which decreased after 5 days of fasting. Liver glycogen decreased after 5 days of fasting while glycogen concentration in muscle did not decrease until 20 days of fasting. Liver color presented a higher chroma after 5 days of fasting, suggesting a mobilization of reserves. Finally, acetylcholinesterase activity in the brain was not affected by food deprivation but increased after 10 days of fasting in liver and muscle, suggesting the mobilization of body reserves, but without severely affecting basal metabolism.

Keywords Food deprivation - Water temperature Rainbow trout $\cdot$ Stress response

\section{Introduction}

In the wild, fish normally cope with long periods without food during migrations and breeding seasons (Hinch et al. 2005; Miller et al. 2009). In aquaculture, fish are usually subjected to short-term fasting during the 
production cycle (i.e., a few days, see López -Luna et al. 2013). Additionally, and depending on environmental conditions (especially in winter), it may not be possible for farmers to feed fish for long periods of time, stretching to weeks in extreme cases (Kiessling et al. 1990). Fasting (typically less than 2 weeks) is different from starvation, which can last several weeks (Pottinger et al. 2003). During the early phases without food (710 days), fish mobilize readily available metabolite reserves like hepatic glycogen (Soengas et al. 1996), while starvation is more associated with a chronic stress response and is thought to have more dramatic consequences on fish metabolism such as pronounced lipid catabolism, inducing changes in fatty acid profiles, as well as an increase in protein catabolism. This response in last term can lead to important effects of fish weight loss (Barcellos et al. 2010).

For aquaculture producers, it may be useful to identify indicators that differentiate between physiological states of fasting and starvation. Although the cutoff point between the two is not always clear, they produce significantly different metabolic states and can be temperature dependent (Neuheimer and Taggart 2007; Chezik et al. 2013), so endocrine control might be expected to differ markedly (Farbridge and Leatherland 1992).

The lack of food can trigger several physiological responses that together are called the stress response. This response consists of a chain of reactions promoted by a stressor, starting in fish with the neuroendocrine responses, called primary responses, including the rapid release of hormones into the circulation, such as catecholamines and cortisol (Belanger et al. 2001). This is followed by the secondary stress response, which includes various biochemical and physiological changes mediated by hormones liberated in the primary response and leads to hematological, osmo-ionic, and metabolic changes (Oliveira et al. 2011; Simonato et al. 2013). These events will lead to the tertiary response, resulting in a decrease of growth performance or reproductive capacity, as well as the ability to cope with other stressful situations (Wendelaar Bonga 1997).

Most of the theory about starvation physiology is based on experiments using birds and mammals as experimental units. In endotherms, starving animals undergo three different physiological and/or morphological phases which are distinguished by changes in body mass, metabolites, and hormone levels in plasma or enzyme activities related to glucose metabolism (McCue 2010). However, in fish, starvation physiology is different because ambient temperature has a large effect on their metabolic processes (Bar and Volkoff 2012). Generally, fish grown in colder water are better adapted to starvation than warm water fish, probably since winter is associated with low food availability and reduced activity (Binner et al. 2008). Therefore, we must take into account the water temperature when studying the duration of food deprivation periods in aquaculture and it is recommended to express this period in cumulative degree days $\left({ }^{\circ} \mathrm{C} \mathrm{d}\right)$, the sum of the average temperatures of the fasting days. This approach is uncommon in aquaculture research, being used only in $5 \%$ of all the studies related to temperature and growth between 1980 and 2006 (Neuheimer and Taggart 2007), but the European Food Safety Authority (EFSA 2008) indicates that it is not possible to specify an exact maximum duration of the fast in terms of time only, since its impact on animal welfare depends on water temperature, among other factors.

Feeding habits are also important since carnivorous fish, like rainbow trout, typically feed less frequently than omnivorous and herbivorous fish (Bond 1996; Armstrong and Schindler 2011), and previous studies show that rainbow trout fed once every 2 days during a month had a lower stress response after pre-slaughter fasting (Bermejo-Poza et al. 2015). It is unclear, however, how rainbow trout are affected by different periods of fasting and starvation in terms of degree days and how that may affect their welfare. In this study, we evaluated the physio-metabolic response to prolonged food deprivation in rainbow trout metabolism and compared to short-term fasting.

\section{Material and methods}

Experimental design and fish

The trial was carried out at the aquaculture facilities of the School of Forestry Engineering (Madrid, Spain), located on a small slope where the downward water flow is distributed among different raceways. For the experiment, four parallel raceways (volume $5.16 \mathrm{~m}^{3}$ ) were filled with freshwater from an underground well, supplying a constant water flow (recirculation) and dissolved oxygen ( $8 \mathrm{mg} \mathrm{O}_{2} / \mathrm{L}$ ). During the whole experiment, animals were subjected to natural photoperiod (10L:14D). To calculate degree days, water temperature was recorded once every $30 \mathrm{~min}$ during the whole trial 
using temperature sensors (Hobo-U11, ONSET, Bourne, MA, USA) averaging $10.2 \pm 1.1^{\circ} \mathrm{C}$. Each raceway was split into six separate sections with the same water volume $\left(0.86 \mathrm{~m}^{3}\right)$ using stainless steel separators with grids, allowing the passage of water from one section to another. In this study, 432 rainbow trout, with an initial weight of $225 \pm 5.78 \mathrm{~g}$ (mean weight \pm SEM), obtained from a farm (Cifuentes, Guadalajara, Spain) were randomly distributed into 24 groups of 18 individuals per compartment (six groups per treatment were in the same raceway). Each group was subjected to either no fasting (0D), to a pre-slaughter fast of 5 days $\left(55^{\circ} \mathrm{C} \mathrm{d} ; 5 \mathrm{D}\right), 10$ days $\left(107{ }^{\circ} \mathrm{C} \mathrm{d} ; 10 \mathrm{D}\right)$, or 20 days $\left(200{ }^{\circ} \mathrm{C} \mathrm{d}\right.$; 20D). Using this experimental design, we could evaluate each experimental condition six times.

Fish were fed $1 \%$ body weight of commercial feed (42\% crude protein, $23 \%$ fat, $4.1 \%$ ash, and $2.0 \%$ crude fiber, $30 \mathrm{ppm}$ astaxanthin), in compliance with recommendations for rainbow trout.

\section{Blood and tissue sampling}

At the end of each experimental period $(0,5,10$, or 20 days), trout were captured with dip nets and electrically stunned (head only, $90 \mathrm{~W}, 2 \mathrm{~s}$ ). Then, they were weighed and fork length measured to calculate the condition factor as indicated in Table 1.

Subsequently, two blood samples of $1 \mathrm{~mL}$ were taken from the caudal vein from 12 trout per compartment. The first blood sample was collected in pre-filled syringes with dry balanced heparin (PICO50 (), Radiometer Medical Aps, Copenhagen, Denmark) for blood assays. For the evaluation of the remaining parameters (cortisol, glucose, lactate dehydrogenase-LDH activity, triglycerides, nonesterified fatty acids, osmolality, total proteins, albumin, and globulin), a second blood sample was obtained and placed into lithium heparinized tubes that were centrifuged at $1200 \mathrm{~g}$ for $15 \mathrm{~min}$ to obtain the plasma, which was frozen at $-60{ }^{\circ} \mathrm{C}$ until further analysis. After blood sampling, fish were killed immediately $(<15 \mathrm{~s})$ by sectioning the spinal cord at the base of the head. Immediately after slaughter, each fish was eviscerated and stomach content was weighed to calculate the empty body weight (fish weight-stomach content) and \% relative weight of the stomach contents. Digestive tract (from stomach to anus, including visceral fat), liver and spleen weights were weighed to calculate biometric parameters. Before removing stomach content, gastric $\mathrm{pH}$ was measured using a $\mathrm{pH}$ meter (HANNA, mod. HI9125) inserting its probe into the stomach. We sampled the liver of gutted fish, the dorsal musculature (at the level of the dorsal fin), and brain, freezing immediately in liquid nitrogen for later determinations of liver and muscle glycogen concentration, liver fatty acid composition and acetylcholinesterase (AChE) activity of liver, muscle, and brain.

\section{Assay procedures}

After collection, blood samples were analyzed immediately ( $<5 \mathrm{~min})$ in an ABL90FLEX (B)blood gas analyzer

Table 1 Biometric parameters, stomach content, and gastric $\mathrm{pH}$ of rainbow trout with different fasting times

\begin{tabular}{|c|c|c|c|c|c|}
\hline & \multicolumn{4}{|l|}{ Fasting time } & \multirow[t]{2}{*}{$p$ value } \\
\hline & $0 \mathrm{D}$ & $5 \mathrm{D}$ & $10 \mathrm{D}$ & $20 \mathrm{D}$ & \\
\hline Fish weight (g) & $270 \pm 4.25^{\mathrm{a}}$ & $260 \pm 3.68^{\mathrm{ab}}$ & $250 \pm 4.26^{\mathrm{b}}$ & $229 \pm 3.57^{\mathrm{c}}$ & $<0.001$ \\
\hline Fork length $(\mathrm{cm})$ & $25.1 \pm 0.32$ & $25.8 \pm 0.29$ & $25.4 \pm 0.38$ & $24.9 \pm 0.35$ & 0.31 \\
\hline $\mathrm{CF}$ & $1.68 \pm 0.04^{\mathrm{a}}$ & $1.58 \pm 0.03^{\mathrm{ab}}$ & $1.53 \pm 0.04^{\mathrm{b}}$ & $1.49 \pm 0.04^{\mathrm{b}}$ & 0.002 \\
\hline DSI $(\%)$ & $7.49 \pm 0.34^{\mathrm{a}}$ & $6.26 \pm 0.20^{\mathrm{b}}$ & $6.30 \pm 0.25^{\mathrm{b}}$ & $6.07 \pm 0.37^{\mathrm{b}}$ & $<0.001$ \\
\hline Stomach content $(\%)$ & $12.38 \pm 2.06^{\mathrm{a}}$ & $3.53 \pm 0.55^{\mathrm{b}}$ & $3.84 \pm 1.28^{\mathrm{b}}$ & $2.89 \pm 0.52^{b}$ & $<0.001$ \\
\hline Gastric $\mathrm{pH}$ & $2.68 \pm 0.20^{\mathrm{c}}$ & $2.21 \pm 0.10^{\mathrm{c}}$ & $3.52 \pm 0.17^{\mathrm{b}}$ & $4.44 \pm 0.15^{\mathrm{a}}$ & $<0.001$ \\
\hline HSI (\%) & $1.33 \pm 0.07^{\mathrm{a}}$ & $1.14 \pm 0.04^{\mathrm{ab}}$ & $1.05 \pm 0.04^{\mathrm{b}}$ & $1.02 \pm 0.08^{\mathrm{b}}$ & $<0.001$ \\
\hline SSI $(\%)$ & $0.34 \pm 0.02$ & $0.36 \pm 0.02$ & $0.44 \pm 0.04$ & $0.43 \pm 0.03$ & 0.06 \\
\hline
\end{tabular}

Values are mean $\pm \mathrm{SEM}, n=108$ per treatment. ${ }^{\mathrm{a}, \mathrm{b}, \mathrm{c}}$ Different superscripts within a row indicate significant differences among fasting times $(p<0.05) . C F$ (condition factor) $=$ fish weight $(\mathrm{g}) /$ fork length $(\mathrm{cm})^{3} ; D S I$ (digestive somatic index $)=$ digestive tract $(\mathrm{g}) / \mathrm{empty}$ body weight $(\mathrm{g}) \times 100 ;$ HSI (hepato-somatic index $)=$ liver weight $(\mathrm{g}) /$ empty body weight $(\mathrm{g}) \times 100 ; S S I$ (spleen somatic index $)=$ spleen weight $(\mathrm{g}) / \mathrm{empty}$ body weight $(\mathrm{g}) \times 100.0 D$, no fasting; $5 D, 5$ days or 55 degree days $\left({ }^{\circ} \mathrm{C} \mathrm{d}\right) ; 10 D, 10$ days or $107^{\circ} \mathrm{C}$ d; $20 D, 20$ days or $200{ }^{\circ} \mathrm{C} \mathrm{d}$ 
(Radiometer Medical Aps, Copenhagen, Denmark) for determination of $\mathrm{pH}$, ionogram (sodium, potassium, chloride, and ionic calcium), and lactate levels. In plasma obtained of second blood sample, cortisol was measured by enzyme immunoassay using a commercial Cortisol EIA well kit (Radim Ibérica S.A., Barcelona, Spain). Plasma concentrations of glucose and triglycerides were determined using reflectance spectrophotometry (Reflotron ${ }^{\circledR}$ System, Roche Diagnostics, IN, USA) based on methods described by Trinder (1969) and Bucolo and David (1973), respectively. LDH activity determination was based on Furné et al. (2012), measuring the conversion of pyruvate to lactate by monitoring the oxidation of NADH. The concentrations of nonesterified fatty acids (NEFA) were determined by enzymatic-colorimetric method using commercial kits (Randox Diagnostic, London, UK). Total plasma proteins were quantified by refractometry (ATAGo T2$\mathrm{Ne}(\mathbb{B})$, Atago, Tokyo, Japan). The albumin concentration was measured by bromocresol green method (Boehringer Mannhein) and globulin concentration as the difference between total protein concentration and albumin. Osmolality was assessed in $50 \mu \mathrm{L}$ of plasma by measuring freezing point in an osmometer (Fiske one-Ten $($, Fiske Co, MA, USA).

Liver and muscle samples were homogenized with perchloric acid to determine glycogen concentration as described by Dreiling et al. (1987). Liver color measurements were taken in fresh liver by triplicate, using a Minolta Spectrophotometer CM-2500c (Minolta, Osaka, Japan). The International Commission on Illumination (CIE) L*a*b* system (CIE 1978) was chosen as the color scale. Using $\mathrm{a}^{*}$ and $\mathrm{b}^{*}$ parameters, we calculated chroma $\left(\mathrm{C}^{*}\right)$ and hue $\left(\mathrm{h}^{*}\right)$ as indicated in Table 2.
Fatty acid methyl esters (FAMES) were formed in duplicate according to Lee et al. (2012). The final organic layers with the FAMES were transferred to a $2-\mathrm{mL}$ vial, then capped and stored at $-20^{\circ} \mathrm{C}$ until analysis. FAMES were analyzed by gas chromatography with flame ionization detection (Perkin-Elmer Autosystem1: A, MA, USA). Results were expressed as a percentage of the total FAMES.

Liver, muscle, and brain samples were homogenized with a phosphate buffer $\mathrm{pH} 80.1 \mathrm{M}$ to determine the activity of AChE based on Ellman et al. (1961), with acetylthiocholine iodide $0.075 \mathrm{M}$ and dithiobisnitrobenzoic acid (DTNB) $0.01 \mathrm{M}$ as substrates. Absorbance was measured at $412 \mathrm{~nm}$ for $3 \mathrm{~min}$ at intervals of $36 \mathrm{~s}$.

\section{Statistical analysis}

The data were analyzed using SAS software ver. 9.0 (Statistical Analysis System Institute Inc., Cary, NC, USA). A prior analysis of the normality and homogeneity of variance of all variables was performed using the Shapiro-Wilk test with the UNIVARIATE procedure and Bartlett's test with the ANOVA procedure for residues. When parameters did not meet the two assumptions, the variables were transformed. The tables present the back-transformed mean values for easier interpretation of the results, although the standard errors of the mean (SEM) and significance values are presented for transformed variables. We used the GLM procedure of SAS, with fasting times as fixed effect. The Bonferroni test was used as a post hoc test $(p<0.05)$.

Table 2 Liver/muscle glycogen and liver color parameters (lightness, $\mathrm{L}^{*}$; chroma, $\mathrm{C}^{*}$; and hue, $\mathrm{h}^{*}$ ) of rainbow trout with different fasting times

\begin{tabular}{|c|c|c|c|c|c|}
\hline & \multicolumn{4}{|l|}{ Fasting time } & \multirow[t]{2}{*}{$p$ value } \\
\hline & $0 \mathrm{D}$ & $5 \mathrm{D}$ & $10 \mathrm{D}$ & $20 \mathrm{D}$ & \\
\hline Liver glycogen (mg/g) & $177.3 \pm 10.08^{\mathrm{a}}$ & $110.7 \pm 10.46^{\mathrm{b}}$ & $61.8 \pm 7.37^{\mathrm{c}}$ & $40.5 \pm 3.62^{\mathrm{c}}$ & $<0.001$ \\
\hline Muscle glycogen (mg/g) & $6.80 \pm 0.51^{\mathrm{a}}$ & $8.07 \pm 2.68^{\mathrm{a}}$ & $6.85 \pm 0.48^{\mathrm{a}}$ & $4.92 \pm 0.39^{\mathrm{b}}$ & $<0.001$ \\
\hline $\mathrm{L}^{*}$ & $28.7 \pm 0.76$ & $26.6 \pm 0.85$ & $27.1 \pm 0.84$ & $25.8 \pm 0.79$ & 0.08 \\
\hline $\mathrm{C}^{*}$ & $13.4 \pm 0.38^{\mathrm{b}}$ & $15.5 \pm 0.47^{\mathrm{a}}$ & $15.9 \pm 0.40^{\mathrm{a}}$ & $15.1 \pm 0.59^{\mathrm{ab}}$ & 0.004 \\
\hline $\mathrm{h}^{*}\left({ }^{\circ}\right)$ & $46.5 \pm 1.83$ & $41.0 \pm 1.84$ & $43.2 \pm 1.70$ & $44.2 \pm 2.66$ & 0.12 \\
\hline
\end{tabular}

Values are mean \pm SEM, $n=36$ per treatment. ${ }^{\text {a, } b, c}$ Different superscripts within a row indicate significant differences among fasting times

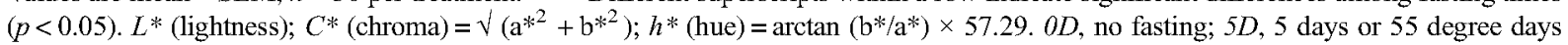
$\left({ }^{\circ} \mathrm{C} \mathrm{d}\right) ; 10 D, 10$ days or $107^{\circ} \mathrm{C} \mathrm{d} ; 20 D, 20$ days or $200^{\circ} \mathrm{C} \mathrm{d}$ 


\section{Results}

Morphometric measurements and gastric $\mathrm{pH}$

Most biometric parameters and the gastric $\mathrm{pH}$ varied significantly with fasting (Table 1). Fish weight and condition factor decreased with fasting, with similar levels between $0 \mathrm{D}$ and 5D trout. Fork length did not differ statistically among treatments. Digestive somatic index and stomach content were higher in 0D trout than in the other groups. Conversely, gastric $\mathrm{pH}$ was lower in trout of groups $0 \mathrm{D}$ and $5 \mathrm{D}$ than $10 \mathrm{D}$ and 20D. The hepato-somatic index was lower in 10D and 20D trout, with similar levels between 0D and 5D trout. Spleen somatic index showed no significant differences between groups.

Blood and plasma parameters

Blood and plasma parameters data are presented in Fig. 1. Glucose levels decreased significantly with fasting, with similar levels between $0 \mathrm{D}$ and $5 \mathrm{D}$ trout. The 20D trout had the lowest plasmatic levels of lactate compared to the other groups. Fasting produced a significant decrease in plasma triglycerides compared to levels found in $0 \mathrm{D}$ trout. Conversely, NEFA increased with fasting, being the highest in 20D trout. Total plasma proteins and globulin were lower in 10D and 20D trout, showing similar levels in $0 \mathrm{D}$ and $5 \mathrm{D}$ trout. The albumin/globulin ratio was lower in $0 \mathrm{D}$ trout than $20 \mathrm{D}$. Finally, chloride ion concentration was lower in $0 \mathrm{D}$ trout than that in the rest of the groups. The remaining parameters (cortisol, $\mathrm{LDH}$, osmolality, $\mathrm{pH}$, albumin, sodium, potassium, and calcium ion) showed no significant differences among fasting times.

Liver/muscle glycogen and liver color

Liver glycogen was highest in $0 \mathrm{D}$ trout and decreased significantly with fasting, and 20D trout had the lowest value of muscle glycogen, being similar among the other groups. Liver $L^{*}$ and $\mathbf{h}^{*}$ were not significantly different but liver $\mathrm{C}^{*}$ increased with fasting, being lowest in 0D trout (Table 2).

Fatty acid composition of liver

The fatty acid composition of liver from each fasting treatment is presented in Table 3 . The proportion of total saturated fatty acids (SFA), C15:0, C16:0, and C17:0 increased with days of fasting, being significantly lower in $0 \mathrm{D}$ trout than the rest of the groups. Myristic acid (C14:0) was lower in 10D and 20D trout, with similar levels between $0 \mathrm{D}$ and 5D trout. Stearic acid (C18:0) increased in 5D and 10D trout but 20D fish presented similar levels as 0D. Monounsaturated fatty acids (MUFA) presented few significant differences due to fasting, with the lowest proportion of myristoleic acid (C14:1) occurring in 0D trout and highest proportion of oleic acid (C18:1) in 20D trout, being similar between other groups. Apart from linolenic acid (C18:3 n-3), which did not vary significantly with fasting time, the proportion of polyunsaturated fatty acids (PUFA) decreased with fasting.

\section{Acetylcholinesterase activity}

The activity of acetylcholinesterase enzyme in liver and muscle increased with fasting, being significantly higher in 10D and 20D trout, while brain acetylcholinesterase activity presented no differences among fasting times (Fig. 2).

\section{Discussion}

Morphometric measurements and gastric $\mathrm{pH}$

In the present study, a 10 -day fast $\left(107^{\circ} \mathrm{C}\right.$ d) caused a significant decrease in fish weight and condition factor compared to controls, which coincides with other studies that report a decrease in body weight in rainbow trout after 1 to 6 weeks without food (Sumpter et al. 1991; Pottinger et al. 2003; Bermejo-Poza et al. 2017). The lack of a difference between $0 \mathrm{D}$ and $5 \mathrm{D}$ trout sustains the hypothesis that fish can quickly adjust their metabolic rate according to food availability (Lines and Spence 2012). In addition, other authors have observed that short-term fasting increases tolerance to stress, reducing the stress response during handling procedures in aquaculture production (Davis and Gaylord 2011), which could be due to physiological changes during non-feeding periods that allow them to use stored energy reserves for metabolic maintenance (Navarro and Gutierrez 1995). Apart from live weight, condition factor also proved to be a valuable index to measure fasting stress (Bavcevic et al. 2010; Chatzifotis et al. 2011), since it decreased starting after 10 days without food. 

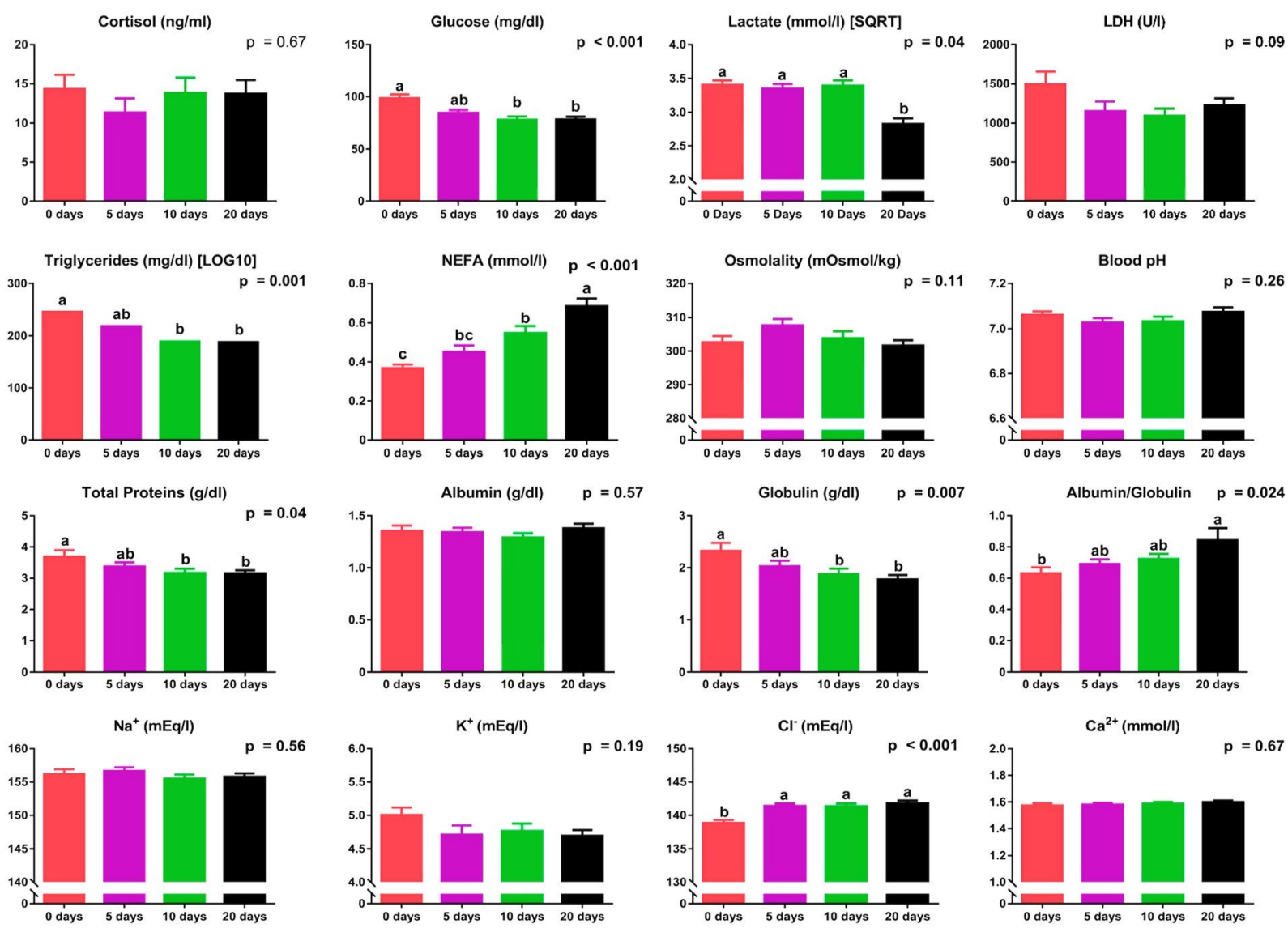

Fig. 1 Biochemical parameters in blood and plasma of rainbow trout at different fasting times (mean $\pm \mathrm{SEM}, n=72$ per treatment). Different superscripts indicate significant differences among fasting times $(p<0.05)$. Transformation data for parameters when

Both stomach content and digestive somatic index (DSI) decreased in $5 \mathrm{D}$ trout $\left(55^{\circ} \mathrm{C} \mathrm{d}\right)$, which agrees with Lines and Spence (2012) and McMillan and Houlihan (1992) who estimated an average of 1-5 days of fasting to ensure a completely empty stomach. Also, previous studies by our research group confirm that 19$23{ }^{\circ} \mathrm{C} \mathrm{d}$ of fasting are enough to empty the stomach in rainbow trout (López-Luna et al. 2013; Bermejo-Poza et al. 2017). However, 10 days of fasting $\left(107^{\circ} \mathrm{C}\right.$ d) were needed to modify gastric $\mathrm{pH}$, increasing it slightly. That is probably due to decreased stimulation of oxynticopeptic cells in the stomach (Ostos Garrido et al. 1993), which decreases the secretion of hydrochloric acid (Yúfera et al. 2012).

As with fish weight and condition factor, hepatosomatic index (HSI) decreased in 10D and 20D trout. During fasting, the mobilization of body energy reserves decreases liver weight in fish (Navarro and Gutierrez
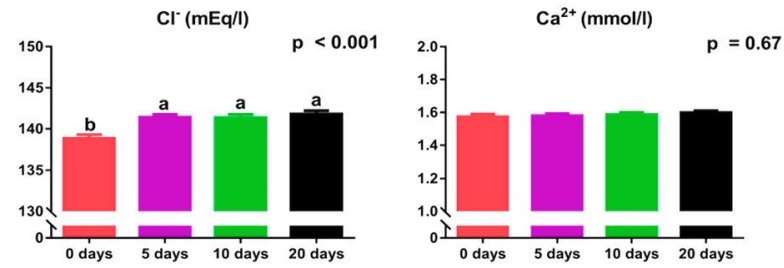

performing analysis of variance: lactate (square root); triglycerides $\left(\log _{10}\right)$. SEM and significance values are presented for transformed data. Means are presented back-transformed for better interpretation

1995; Gisbert et al. 2011; Torfi Mozanzadeh et al. 2017) but it is not always quantified in terms of degree days. The relative size of the liver is correlated with the nutritional condition of the fish (Caruso et al. 2012), so lower HSI values may indicate a depletion of stored nutrients such as fat and glycogen in this organ, as a consequence of food deprivation (Barcellos et al. 2010; Costas et al. 2011; Davis and Gaylord 2011). However, the effect of fasting on the mobilization of liver reserves may vary with species and experimental conditions. According to the literature, 2-6 days of fasting are needed to decrease the HSI in rainbow trout (Farbridge and Leatherland 1992; McMillan and Houlihan 1992), which is sooner than what was found in the current study, although that effect is also probably temperature dependent, since fish metabolism is higher at higher temperatures (Kumar et al. 2013), and would be better expressed in terms of degree days. 
Table 3 Liver fatty acid (FA) profile (expressed as percentage of total FA) of rainbow trout with different fasting times ( $m$ ean $\pm \mathrm{SEM}, n=36$ per treatment)

\begin{tabular}{|c|c|c|c|c|c|}
\hline & \multicolumn{4}{|l|}{ Fasting time } & \multirow[t]{2}{*}{$p$ value } \\
\hline & $0 \mathrm{D}$ & $5 \mathrm{D}$ & $10 \mathrm{D}$ & $20 \mathrm{D}$ & \\
\hline SFA & $47.1 \pm 3.04^{b}$ & $58.6 \pm 0.85^{\mathrm{a}}$ & $60.1 \pm 0.80^{\mathrm{a}}$ & $59.1 \pm 1.86^{\mathrm{a}}$ & $<0.001$ \\
\hline $\mathrm{C} 12: 0$ & $0.06 \pm 0.01$ & $0.06 \pm 0.01$ & $0.08 \pm 0.01$ & $0.07 \pm 0.01$ & 0.28 \\
\hline C14:0 & $2.00 \pm 0.17^{\mathrm{a}}$ & $1.97 \pm 0.05^{\mathrm{a}}$ & $1.41 \pm 0.05^{\mathrm{b}}$ & $1.48 \pm 0.07^{\mathrm{b}}$ & 0.001 \\
\hline $\mathrm{C} 15: 0$ & $0.33 \pm 0.03^{\mathrm{b}}$ & $0.44 \pm 0.01^{\mathrm{a}}$ & $0.44 \pm 0.01^{\mathrm{a}}$ & $0.42 \pm 0.01^{\mathrm{a}}$ & 0.001 \\
\hline $\mathrm{C} 16: 0$ & $32.3 \pm 2.01^{\mathrm{b}}$ & $40.1 \pm 0.61^{\mathrm{a}}$ & $42.3 \pm 0.50^{\mathrm{a}}$ & $43.3 \pm 1.34^{\mathrm{a}}$ & $<0.001$ \\
\hline $\mathrm{C} 17: 0$ & $0.44 \pm 0.05^{\mathrm{b}}$ & $0.60 \pm 0.02^{\mathrm{a}}$ & $0.63 \pm 0.01^{\mathrm{a}}$ & $0.58 \pm 0.02^{\mathrm{a}}$ & 0.001 \\
\hline C18:0 & $11.9 \pm 1.02^{\mathrm{b}}$ & $15.5 \pm 0.47^{\mathrm{a}}$ & $15.2 \pm 0.31^{\mathrm{a}}$ & $13.3 \pm 0.58^{\mathrm{b}}$ & 0.002 \\
\hline MUFA & $30.5 \pm 1.43$ & $32.0 \pm 0.98$ & $32.4 \pm 0.87$ & $33.7 \pm 0.95$ & 0.27 \\
\hline $\mathrm{C} 14: 1$ & $0.10 \pm 0.02^{b}$ & $0.20 \pm 0.01^{\mathrm{a}}$ & $0.19 \pm 0.02^{\mathrm{a}}$ & $0.22 \pm 0.03^{\mathrm{a}}$ & 0.001 \\
\hline C16:1 & $1.91 \pm 0.22$ & $1.64 \pm 0.11$ & $1.53 \pm 0.05$ & $1.58 \pm 0.08$ & 0.25 \\
\hline $\mathrm{C} 17: 1$ & $0.14 \pm 0.01$ & $0.14 \pm 0.01$ & $0.14 \pm 0.01$ & $0.13 \pm 0.02$ & 0.94 \\
\hline C18:1 & $25.1 \pm 1.10^{\mathrm{b}}$ & $26.7 \pm 0.78^{b}$ & $27.9 \pm 0.90^{\mathrm{b}}$ & $29.0 \pm 0.84^{\mathrm{a}}$ & 0.032 \\
\hline $\mathrm{C} 20: 1 \mathrm{n}-9$ & $3.30 \pm 0.32$ & $3.33 \pm 0.20$ & $2.67 \pm 0.19$ & $2.76 \pm 0.11$ & 0.10 \\
\hline PUFA & $22.4 \pm 4.30^{\mathrm{a}}$ & $9.39 \pm 0.96^{\mathrm{b}}$ & $7.52 \pm 0.88^{\mathrm{b}}$ & $7.14 \pm 0.98^{\mathrm{b}}$ & 0.001 \\
\hline C18:2 & $4.41 \pm 0.49^{\mathrm{a}}$ & $3.05 \pm 0.25^{\mathrm{b}}$ & $3.10 \pm 0.23^{b}$ & $2.63 \pm 0.24^{\mathrm{b}}$ & 0.004 \\
\hline C18:3 n-3 & $0.40 \pm 0.07$ & $0.25 \pm 0.04$ & $0.26 \pm 0.06$ & $0.34 \pm 0.04$ & 0.21 \\
\hline $\mathrm{C} 20: 2$ & $1.18 \pm 0.15^{\mathrm{a}}$ & $0.54 \pm 0.06^{\mathrm{b}}$ & $0.41 \pm 0.04^{\mathrm{b}}$ & $0.29 \pm 0.03^{\mathrm{b}}$ & $<0.001$ \\
\hline$C 20: 3 n-6$ & $0.79 \pm 0.18^{\mathrm{a}}$ & $0.29 \pm 0.03^{b}$ & $0.19 \pm 0.02^{b}$ & $0.17 \pm 0.03^{b}$ & 0.001 \\
\hline $\mathrm{C} 20: 4 \mathrm{n}-6$ & $2.63 \pm 0.55^{\mathrm{a}}$ & $1.14 \pm 0.15^{\mathrm{b}}$ & $0.81 \pm 0.13^{\mathrm{b}}$ & $0.70 \pm 0.11^{\mathrm{b}}$ & 0.001 \\
\hline $\mathrm{C} 20: 5 \mathrm{n}-3$ & $2.26 \pm 0.47^{\mathrm{a}}$ & $0.93 \pm 0.12^{b}$ & $0.49 \pm 0.02^{b}$ & $0.69 \pm 0.15^{b}$ & 0.001 \\
\hline $\mathrm{C} 22: 5 \mathrm{n}-3$ & $0.76 \pm 0.17^{\mathrm{a}}$ & $0.19 \pm 0.03^{b}$ & $0.13 \pm 0.02^{b}$ & $0.16 \pm 0.03^{b}$ & $<0.001$ \\
\hline $\mathrm{C} 22: 6 \mathrm{n}-3$ & $10.0 \pm 2.33^{\mathrm{a}}$ & $3.00 \pm 0.42^{\mathrm{b}}$ & $2.10 \pm 0.39^{\mathrm{b}}$ & $2.20 \pm 0.41^{\mathrm{b}}$ & 0.001 \\
\hline
\end{tabular}

Values are mean $\pm \mathrm{SEM}, n=36$ per treatment. ${ }^{\mathrm{a}, \mathrm{b}, \mathrm{c}}$ Different superscripts within a row indicate significant differences among fasting times $(p<0.05)$. SFA, total saturated fatty acids; $M U F A$, total monounsaturated fatty acids; $P U F A$, total polyunsaturated fatty acids. $O D$, no fasting; $5 D, 5$ days or 55 degree days $\left({ }^{\circ} \mathrm{C} \mathrm{d}\right) ; 10 D, 10$ days or $107^{\circ} \mathrm{C} \mathrm{d} ; 20 D, 20$ days or $200^{\circ} \mathrm{C} \mathrm{d}$

Blood and plasma parameters

Under a compromised situation, cortisol secretion modulates many biochemical, physiological, and behavioral responses, such as energy metabolism, ion-osmotic regulation, and growth (Mommsen et al. 1999; Ellis et al.
2012). Thus, we expected that plasma cortisol levels would be affected by food deprivation in the current study, but they were similar among groups. Data about the effect of fasting or starvation on cortisol levels in rainbow trout are inconsistent, with studies reporting an increase in plasma cortisol after periods of food
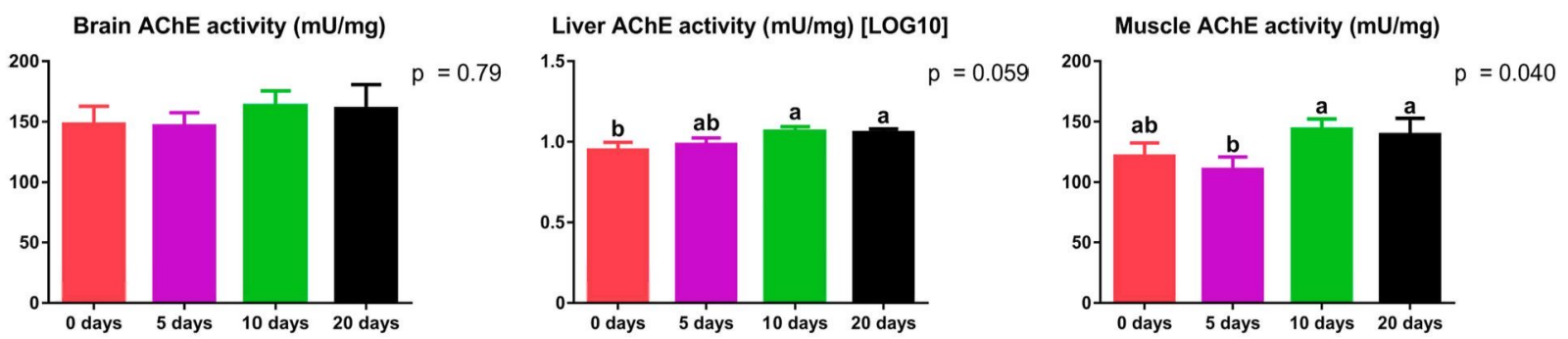

Fig. 2 Acetylcholinesterase (AChE) activity in brain, liver, and muscle of rainbow trout with different fasting times (mean $\pm \mathrm{SEM}, n=36$ per treatment). Different superscripts indicate significant differences among fasting times $(p<0.05)$ 
deprivation (Sumpter et al. 1991), decreased plasma levels (Farbridge and Leatherland 1992), or, as in our case, no effect (Holloway et al. 1994; Reddy et al. 1995). Cortisol contributes to the maintenance of both basal and stress-related homeostasis and varies with temperature, gender, sexual maturity, and genetics (Pottinger 2010), so values tend to be quite variable even among individuals from the same tank/treatment and cannot always be assumed to be related to stress alone (Chrousos and Kino 2009). It should be also considered that cortisol secretion can return to basal values in few days (Ellis et al. 2012), so the lack of changes could be masked after 5 days of fasting.

Regarding the mobilization of body reserves, fasting induces a sequential use of glycogen, lipid, and protein reserves (Collins and Anderson 1995). In the current study, plasma glucose, triglycerides, and total proteins decreased after 10 days of fasting $\left(107^{\circ} \mathrm{C} \mathrm{d}\right)$. Periods of food deprivation around $70^{\circ} \mathrm{C}$ d can induce hypoglycemia in rainbow trout (Furné et al. 2012). The 10D and 20D trout had lower glucose levels than controls but within basal levels, probably since it is an essential fuel for a number of tissues (Costas et al. 2011), but possibly at the expense of glycogen stored in the liver. An increase in plasma lactate levels is one of the earliest responses associated with "urgent" fuel consumption by anaerobic metabolism in fish under stress (Gatica et al. 2010). Then, these values can be restored by a lactate mobilization for gluconeogenic purposes in liver (Polakof et al. 2006; Liew et al. 2012). At 20 days of fasting $\left(200{ }^{\circ} \mathrm{C} \mathrm{d}\right)$, the manifested decrease of plasma lactate might be related to the maintenance of basal glucose levels, which has also been observed in other fasted fish (Soengas et al. 1996; Sangiao-Alvarellos et al. 2005). LDH activity is associated with glucose anaerobic oxidation and used as biomarker for heat stress in fish (Feidantsis et al. 2015). Elevated activity of this enzyme can indicate hepatic, renal, or muscular damage, and this effect can be related to stress stimulus like fasting (Peres et al. 2014). The activity of LDH presented no significant differences between groups, possibly since that requires more degree days of fasting.

Triglycerides are also an important source of energy that fish will use in response to a stressful stimulus such as acclimatizing to different growing densities or fasting (Laiz-Carrión et al. 2012; Millán-Cubillo et al. 2016). As in the case of glucose, plasma triglycerides decreased in 10D trout. Fasting led fish to make notable use of their lipid reserves after 10 days of food deprivation, possibly since glycogenolysis was not sufficient to normalize glucose levels, and this was reflected in reduced plasma triglycerides (Favero et al. 2018). Lipolysis was confirmed by the high levels of NEFA after 10 days of fasting (Polakof et al. 2006; Mancera et al. 2008)

According to Lauff and Wood (1996), the use of protein as a metabolic fuel during feed deprivation accounts for $24 \%$ of the energy needs of rainbow trout. Total plasma protein levels tend to fall after prolonged starvation in several fish species like common carp (Cyprinus carpio) and rainbow trout (Shimeno et al. 1997; Polakof et al. 2007), agreeing with our finding of lower total proteins in plasma after 10 days of fasting. However, fasting did not decrease plasma albumin, as found in food-restricted mammals (Straus et al. 1994; Don and George 2004), but the nutritional regulation of albumin is not well understood in fish (Kawanago et al. 2014). On the other hand, our finding of decreased levels of globulin after 10 days of fasting could indicate an impairment of the immune response, where it plays an important role (Nayak et al. 2004).

Regarding plasma ion levels, there were no differences among treatments, with the exception of an increase in plasma chloride after 5 days of fasting $\left(55^{\circ} \mathrm{C} \mathrm{d}\right)$, which could be since branchial function was affected. Chloride cells play an essential role in maintaining the ionic balance of the internal environment, absorbing $\mathrm{Na}^{+}$and $\mathrm{Cl}^{-}$, which could be affected by stressors like fasting and reduce their function (Simonato et al. 2013). The fact that food-deprived fish maintained a similar concentration of plasma ions as controls despite reduced energy stores is perhaps not surprising as a loss of ionic balance would almost certainly lead to death (Gonzalez and McDonald 1992; Gingerich et al. 2010).

\section{Liver/muscle glycogen and liver color}

As commented above, food deprivation mobilizes nutrients stored in the liver, such as glycogen, especially during the early stages of fasting (Davis and Gaylord 2011). The moment when liver glycogen reserves begin to decrease is variable but is thought to range from 5 to 20 days after food is removed (Sangiao-Alvarellos et al. 2005; Barcellos et al. 2010). Furné et al. (2012) observed that, in rainbow trout, hepatic glycogen is mobilized after 5 days of fasting, which agrees with our results and reflects how glycogen is used to replace the absence of dietary carbohydrate intake (Dias Junior 
et al. 2016). However, muscle glycogen did not decrease until 20 days of food deprivation $\left(200{ }^{\circ} \mathrm{C} \mathrm{d}\right)$, possibly because it makes a small contribution to total energy expenditure and can be maintained at the expense of hepatic glucose release (Navarro and Gutiérrez 1995).

Since the liver plays an important role in maintaining homeostasis during fasting, its color is affected and can be used as an indicator of fasting stress in fish (BermejoPoza et al. 2017). After 5 days of fasting, liver chroma increased in the current study, possibly indicating a decrease in lipid concentration, as seen in other animals such as fasted broiler chickens (Trampel et al. 2005). These results showed that liver color can be a good biomarker for stress response produced by fasting, confirmed with previous results of our group (BermejoPoza et al. 2017)

Fatty acid composition of liver

Regarding the fatty acid composition of rainbow trout liver, the results were similar as those of previous studies that reported a higher percentage of saturated and monounsaturated fatty acids than polyunsaturated fatty acids (Bayraktar and Bayir 2012; Suárez et al. 2014; Taşbozan et al. 2016). Overall, after 5 days of fasting, we observed an increase of SFA and decrease of PUFA. The percentage of MUFA was not affected by fasting, except for myristoleic acid (C14:1) and oleic acid (C18:1), which increased at 5 and 20 days of fasting respectively, possibly due to the capacity of freshwater fish to desaturate endogenously the saturated fatty acids synthesized to monounsaturated fatty acids (Tocher 2003). Einen et al. (1998) did not find large differences in the fatty acid profile of salmon subjected to fasting periods of up to 86 days although they observed differences in the desaturase enzymes, specifically in the $\Delta 9$-desaturase. Unfortunately, we did not measure the activity of this enzyme in our study but this could be the reason of the increase of $\mathrm{C} 16: 0$ in fish subjected to fasting.

After 5 days of fasting, our results indicate that trout used their reserves of PUFA, mainly long chain n-3 fatty acids. Zengin et al. (2013) observed that $n-3$ fatty acids are the ones that decrease to a greater extent when used as an energy source.

Acetylcholinesterase activity

In liver and muscle, an increase in acetylcholinesterase $(\mathrm{AChE})$ activity after 10 days of fasting $\left(107^{\circ} \mathrm{C} \mathrm{d}\right)$ could be associated with the proteolytic function of this enzyme. During prolonged starvation (in tissues subject to catabolism), AChE (a protease) levels increase and begin to degrade tissue in mice (Suchiang and Sharma 2011) and fish (Kim and Park, 1995). AChE is also important for many physiological functions in fish, such as prey location, predator evasion, and food orientation (Miron et al. 2005). So, increased AChE activity may also be linked with increased food-seeking behavior during fasting. Levels were similar in the liver and muscle of $0 \mathrm{D}$ and $5 \mathrm{D}$ trout, so it appears that protein catabolism began after 10 days of fasting (when total plasma protein levels also decreased). However, in brain, AChE was not affected, probably since nervous tissue is not normally degraded as a source of energy and most $\mathrm{AChE}$ in the nervous system is used to degrade of acetylcholine (Rodrigues et al. 2011).

\section{Conclusions}

The results of the present study showed that rainbow trout subjected to 20 days $\left(200{ }^{\circ} \mathrm{C} \mathrm{d}\right.$ ) without food undergo a significant decrease in some biometric parameters and plasma metabolites related to energy metabolism. However, all trout maintained their ion homeostasis in plasma, probably at the expense of metabolic energy (Applebaum et al. 2014; Alix et al. 2017). Fasting for 5 days $\left(55^{\circ} \mathrm{C}\right.$ d) had very little effect on the trout, supporting previous studies by our research group showing that rainbow trout can cope well with up to $58^{\circ} \mathrm{C}$ d of fasting with little or no effect on metabolic or stress indicators (López-Luna et al. 2013; Bermejo-Poza et al. 2016; Bermejo-Poza et al. 2017). In conclusion, based on the results obtained in this study, a 5-day fasting period $\left(55^{\circ} \mathrm{C}\right.$ d) had little impact on biometric parameters and mobilization of body reserves, while 10 and 20 days produced important changes in liver weight and plasma concentration of metabolites related to energy metabolism. However, even after 20 days $\left(200{ }^{\circ} \mathrm{C} \mathrm{d}\right)$ of fasting, trout maintained basal levels of plasma ions and brain $\mathrm{AChE}$, which underlines their importance in homeostasis and the preservation of vital functions.

Funding information This project was financed by the Spanish Ministry of Economy and Competitiveness (MINECO), project AGL2013-45557-P. 


\section{References}

Alix M, Blondeau-Bidet E, Grousset E, Shiranghi A, Vergnet A, Guinand B, Chatain B, Boulo V, Lignot JH (2017) Effects of fasting and re-alimentation on gill and intestinal morphology and indicators of osmoregulatory capacity in genetically selected sea bass (Dicentrarchus labrax) populations with contrasting tolerance to fasting. Aquaculture 468:314-325. https://doi.org/10.1016/j.aquaculture.2016.10.016

Applebaum SL, Pan TCF, Hedgecock D, Manahan DT (2014) Separating the nature and nurture of the allocation of energy in response to global change. Integr Comp Biol 54:284-295. https://doi.org/10.1093/icb/icu062

Armstrong JB, Schindler DE (2011) Excess digestive capacity in predators reflects a life of feast and famine. Nature 476:8487. https://doi.org/10.1038/nature10240

Bar N, Volkoff H (2012) Adaptation of the physiological, endocrine, and digestive system functions to prolonged food deprivation in fish. In: McCue MD (ed) Comparative physiology of fasting, starvation, and food limitation. Springer, Heidelberg, pp 69 89. https://doi.org/10.1007/978-3-642-29056-5_6

Barcellos L, Marqueze A, Trapp M, Quevedo RM, Ferreira D (2010) The effects of fasting on cortisol, blood glucose and liver and muscle glycogen in adult jundiá Rhamdia quelen. Aquaculture 300:231-236. https://doi.org/10.1016/j. aquaculture.2010.01.013

Bavcevic L, Klanjscek T, Karamarko V, Anicic I, Legovic T (2010) Compensatory growth in gilthead sea bream (Sparus aurata) compensates weight, but not length. Aquaculture 301:57-63. https://doi.org/10.1016/j.aquaculture. 2010.01.009

Bayraktar K, Bayır A (2012) The effect of the replacement of fish oil with animal fats on the growth performance, survival and fatty acid profile of rainbow trout juveniles, Oncorhynchus mykiss. Turk J Fish Aquat Sci 12:661-666. https://doi. org/10.4194/1303-2712-v12_3_14

Belanger JM, Son JH, Laugero KD, Moberg GP, Doroshov SI, Lankford SE, Cech JJ Jr (2001) Effects of short-term management stress and $\mathrm{ACTH}$ injections on plasma cortisol levels in cultured white sturgeon, Acipenser transmontanus. Aquaculture 203:165-176. https://doi.org/10.1016/S00448486(01)00620-2

Bermejo-Poza R, De la Fuente J, Pérez C, Lauzurica S, González E, Diaz MT, Villarroel M (2015) The effect of intermittent feeding on the pre-slaughter fasting response in rainbow trout. Aquaculture 443:24-30. https://oi.org/10.1016/j. aquaculture.2015.03.007

Bermejo-Poza R, De la Fuente J, Pérez C, Lauzurica S, González de Chávarri E, Diaz MT, Villarroel M (2016) Reducing the effect of pre-slaughter fasting on the stress response of rainbow trout (Oncorhynchus mykiss). Anim Welf 25:339-346. https://doi.org/10.7120/09627286.25.3.339

Bermejo-Poza R, De la Fuente J, Pérez C, González de Chavarri EG, Diaz MT, Torrent F, Villarroel M (2017) Determination of optimal degree days of fasting before slaughter in rainbow trout (Oncorhynchus mykiss). Aquaculture 473:272-277. https://doi.org/10.1016/j.aquaculture.2017.01.036

Binner M, Kloas W, Hardewig I (2008) Energy allocation in juvenile roach and burbot under different temperature and feeding regimes. Fish Physiol Biochem 34:103-116. https://doi.org/10.1007/s10695-007-9151-8
Bond CE (1996) Nervous and endocrine systems. In: Bond CE (ed) Biology of fishes. Saunders College Publishing, Fort Worth, pp 241-258

Bucolo G, David H (1973) Quantitative determination of serum triglycerides by the use of enzymes. Clin Chem 19:476-482

Caruso G, Denaro MG, Caruso R, Genovese L, Mancari F, Maricchiolo G (2012) Short fasting and refeeding in red porgy (Pagrus, Linnaeus 1758): response of some haematological, biochemical and non specific immune parameters. Mar Environ Res 81:18-25. https://doi.org/10.1016/j. marenvres.2012.07.003

Chatzifotis S, Papadaki M, Despoti S, Roufidou C, Antonopoulou $E$ (2011) Effect of starvation and re-feeding on reproductive indices, body weight, plasma metabolites and oxidative enzymes of sea bass (Dicentrarchus labrax). Aquaculture 316: 53-59. https://doi.org/10.1016/j.aquaculture.2011.02.044

Chezik KA, Lester NP, Venturelli PA (2013) Fish growth and degree-days I: selecting a base temperature for a withinpopulation study. Can J Fish Aquat Sci 71:47-55. https://oi.org/10.1139/cjfas-2013-0295

Chrousos GP, Kino T (2009) Glucocorticoid signalling in the cell. Expanding clinical implications to complex human behavioral and somatic disorders. Ann N Y Acad Sci 1176:153166. https://doi.org/10.1111/j.1749-6632.2009.04988.x

CIE (Commission Internationale de l' Eclairage) (1978) Recommendations on Uniform Color Spaces Color Difference Equations, Psychometric Color Terms. Supplement No 2 to CIE Publication No 15. Colorimetry. Bureau Central de la CIE, Paris, France.

Collins AL, Anderson TA (1995) The regulation of endogeneous energy stores during starvation and refeeding in the somatic tissues of the golden perch. J Fish Biol 47:1004-1015. https://doi.org/10.1111/j.1095-8649.1995.tb06024.x

Costas B, Aragao C, Ruiz-Jarabo I, Vargas-Chacoff L, Arjona FJ, Dinis MT, Mancera JM, Conceiçao L (2011) Feed deprivation in Senegalese sole (Solea senegalensis Kaup, 1858) juveniles: effects on blood plasma metabolites and free amino acid levels. Fish Physiol Biochem 37:495-504. https://oi. org/10.1007/s10695-010-9451-2

Davis KB, Gaylord TG (2011) Effect of fasting on body composition and responses to stress in sunshine bass. Comp Biochem Physiol A 158:30-36. https://doi.org/10.1016/j.cbpa.2010.08.019

Dias Junior W, Baviera AM, Zanon NM, Galban VD, Garófalo MAR, Machado CR, Bailão EFLC, Kettelhut IC (2016) Lipolytic response of adipose tissue and metabolic adaptations to long periods of fasting in red tilapia (Oreochromis sp., Teleostei: Cichlidae). An Acad Bras Ciênc 88:17431754. https://doi.org/10.1590/0001-3765201620150484

Don BR, George K (2004) Poor nutritional status and inflammation: serum albumin: relationship to inflammation and nutrition. Semin Dial 17:432-437. https://doi.org/10.1111/j.08940959.2004.17603.x

Dreiling CE, Brown DE, Casale L, Kelly L (1987) Muscle glycogen: comparison of iodine binding and enzyme digestion assays and application to meat samples. Meat Sci 20:167177. https://doi.org/10.1016/0309-1740(87)90009-X

Einen O, Waagan B, Thomassen MS (1998) Starvation prior to slaughter in Atlantic salmon (Salmo salar): I. Effects on weight loss, body shape, slaughter-and fillet-yield, proximate and fatty acid composition. Aquaculture 166:85-104. https://doi.org/10.1016/S0044-8486(98)00279-8 
Ellis T, Yildiz HY, López-Olmeda J, Spedicato MT, Tort L, Øverli $\varnothing$, Martins CI (2012) Cortisol and finfish welfare. Fish Physiol Biochem 38:163-188. https://doi.org/10.1007 /s 10695-011-9568-y

Ellman GL, Courtney D, Andres VJ, Featherstone RM (1961) A new and rapid colorimetric determination of acetylcholinesterase activity. Biochem Pharmacol 7:88IN191-88I9095. https://doi.org/10.1016/0006-2952(61)90145-9

European Food Safety Authority EFSA (2008) Animal welfare aspects of husbandry systems for farmed trout. Scientific opinion of the Panel on Animal Health and Animal Welfare. EFSA J 796:1-22. https://doi.org/10.2903/j. efsa. 2008.796

Farbridge KJ, Leatherland JF (1992) Temporal changes in plasma thyroid hormone, growth hormone and free fatty acid concentrations, and hepatic 5'-monodeiodinase activity, lipid and protein content during chronic fasting and re-feeding in rainbow trout (Oncorhynchus mykiss). Fish Physiol Biochem 10: 245-257. https://doi.org/10.1007/BF00004518

Favero GC, Gimbo RY, Franco Montoya LN, Zanuzzo FS, Urbinati EC (2018) Fasting and refeeding lead to more efficient growth in lean pacu (Piaractus mesopotamicus). Aquac Res 49:359-366. https://doi.org/10.1111/are.13466

Feidantsis K, Pörtner HO, Antonopoulou E, Michaelidis B (2015) Synergistic effects of acute warming and low $\mathrm{pH}$ on cellular stress responses of the gilthead seabream Sparus aurata. J Comp Physiol B 185:185-205. https://doi.org/10.1007 /s00360-014-0875-3

Furné M, Morales AE, Trenzado CE, García-Gallego M, Hidalgo MC, Domezain A, Rus AS (2012) The metabolic effects of prolonged starvation and refeeding in sturgeon and rainbow trout. J Comp Physiol B 182:63-76. https://doi.org/10.1007 /s00360-011-0596-9

Gatica MC, Monti GE, Knowles TG, Warriss PD, Gallo CB (2010) Effects of commercial live transportation and preslaughter handling of Atlantic salmon on blood constituents. Arch Med Vet 42:73-78. https://doi.org/10.4067/\$0301-732 X2010000100010

Gingerich AJ, Philipp DP, Suski CD (2010) Effects of nutritional status on metabolic rate, exercise and recovery in a freshwater fish. J Comp Physiol B 180:371-384. https://doi.org/10.1007 /s00360-009-0419-4

Gisbert E, Fernández I, Alvarez-González CA (2011) Prolonged feed deprivation does not permanently compromise digestive function in migrating European glass eels Anguilla. J Fish Biol 78: 580-592. https://doi.org/10.1111/j.1095-8649.2010.02879.x

Gonzalez RJ, McDonald DG (1992) The relationship between oxygen consumption and ion loss in a freshwater fish. J Exp Biol 163:317-332

Hinch SG, Cooke SJ, Healey MC, Farrell AP (2005) Behavioural physiology of fish migrations: salmon as a model approach. Fish Physiol 24:239-295. https://doi.org/10.1016/S15465098(05)24007-4

Holloway AC, Reddy PK, Sheridan MA, Leatherland JF (1994) Diurnal rhythms of plasma growth hormone, somatostatin, thyroid hormones, cortisol and glucose concentrations in rainbow trout, Oncorhynchus mykiss, during progressive food deprivation. Biol Rhythm Res 25:415-432. https://doi. org/10.1080/09291019409360312

Kawanago M, Takemura S, Ishizuka R, Shioya I (2014) Plasma components and hepatic insulin-like growth factor expression indicate nutritional status in yellowtail Seriola quinqueradiata. N Am J Aquac 76:143-152. https://oi. org/10.1080/15222055.2014.886649

Kiessling A, Johansson L, Kiessling KH (1990) Effects of starvation on rainbow trout muscle: I. Histochemistry, metabolism and composition of white and red muscle in mature and immature fish. Acta Agric Scand 40:309-324. https://doi. org $/ 10.1080 / 00015129009438565$

Kim HI, Park IK (1995) Effect of prolonged starvation on the activities of malic enzyme and acetylcholinesterase in tissues of Japanese quail. Int J Biochem Cell Biol 27:1161-1167. https://doi.org/10.1016/1357-2725(95)00088-7

Kumar S, Sahu NP, Pal AK, Saravanan S, Priyadarshi H (2013) Short-term exposure to higher temperature triggers the metabolic enzyme activities and growth of fish Labeo rohita fed with high-protein diet. Aquac Nutr 19:186-198. https://doi. org/10.1111/j.1365-2095.2012.00951.x

Laiz-Carrión R, Viana IR, Cejas JR, Ruiz-Jarabo I, Jerez S, Martos JA, Eduardo AB, Mancera JM (2012) Influence of food deprivation and high stocking density on energetic metabolism and stress response in red porgy, Pagrus L. Aquacult Int 20:585-599. https://doi.org/10.1007/s10499-011-9488-y

Lauff RF, Wood CM (1996) Respiratory gas exchange, nitrogenous waste excretion, and fuel usage during starvation in juvenile trout, Oncorhynchus mykiss. J Comp Physiol B 165:542-551. https://doi.org/10.1007/BF00387515

Lee MRF, Tweed JKS, Kim EJ, Scollan ND (2012) Beef, chicken and lamb fatty acid analysis - a simplified direct bimethylation procedure using freeze-dried material. Meat Sci 92:863-866. https://doi.org/10.1016/j.meatsci.2012.06.013

Liew HJ, Sinha AK, Mauro N, Diricx M (2012) Fasting goldfish, Carassius auratus, and common carp, Cyprinus carpio, use different metabolic strategies when swimming. Comp Biochem Physiol A 163:327-335. https://doi.org/10.1016/j. cbpa.2012.07.012

Lines JA, Spence J (2012) Safeguarding the welfare of farmed fish at harvest. Fish Physiol Biochem 38:153-162. https://doi. org/10.1007/s10695-011-9561-5

López-Luna J, Vásquez L, Torrent F, Villarroel M (2013) Shortterm fasting and welfare prior to slaughter in rainbow trout, Oncorhynchus mykiss. Aquaculture 400:142-147. https://doi.org/10.1016/j.aquaculture.2013.03.009

Mancera JM, Vargas-Chacoff L, García-López A, Kleszczynska A, Kalamarz H, Martínez-Rodríguez G, Kulczykowska E (2008) High density and food deprivation affect arginine vasotocin, isotocin and melatonin in gilthead sea bream (Sparus aurata). Comp Biochem Physiol A 149:92-97. https://doi.org/10.1016/j.cbpa.2007.10.016

McCue MD (2010) Starvation physiology: reviewing the different strategies animals use to survive a common challenge. Comp Physiol A 156:1-18. https://doi.org/10.1016/j.cbpa.2010.01.002

McMillan N, Houlihan DF (1992) Protein synthesis in trout liver is stimulated by both feeding and fasting. Fish Physiol Biochem 10:23-34. https://doi.org/10.1007/BF00004651

Millán-Cubillo AF, Martos-Sitcha JA, Ruiz-Jarabo I, Cárdenas S, Mancera JM (2016) Low stocking density negatively affects growth, metabolism and stress pathways in juvenile specimens of meagre (Argyrosomus regius, Asso 1801). Aquaculture 451: 87-92. https://doi.org/10.1016/j.aquaculture.2015.08.034

Miller KM, Schulze AD, Ginther N, Li S, Patterson DA, Farrell AP, Hinch SG (2009) Salmon spawning migration: metabolic 
shifts and environmental triggers. Comp Biochem Physiol D 4:75-89. https://doi.org/10.1016/j.cbd.2008.11.002

Miron DD, Crestani M, Shettinger MR, Morsch VM, Baldisserotto B, Tierno MA, Moraes G, Vieira VLP (2005) Effects of the herbicides clomazone, quinclorac, and metsulfuron methyl on acetylcholinesterase activity in the silver catfish (Rhamdia quelen) (Heptapteridae). Ecotoxicol Environ Saf 61:398403. https://doi.org/10.1016/j.ecoenv.2004.12.019

Mommsen TP, Vijayan MM, Moon TW (1999) Cortisol in teleosts: dynamics, mechanisms of action, and metabolic regulation. Rev Fish Biol Fish 9:211-268. https://doi.org/10.1023 /A: 1008924418720

Navarro I, Gutierrez J (1995) Fasting and starvation. In: Hochachka PW, Mommsen TP (eds) Biochemistry and molecular biology of fishes, vol 4. Elsevier, New York, pp 393 434. https://doi.org/10.1016/S1873-0140(06)80020-2

Nayak AK, Das BK, Kohli MPS, Mukherjee SC (2004) The immunosuppressive effect of $\alpha$-permethrin on Indian major carp, Rohu (Labeo rohita Ham.). Fish Shellfish Immunol 16: 41-50. https://doi.org/10.1016/S1050-4648(03)00029-9

Neuheimer AB, Taggart CT (2007) The growing degree-day and fish size-at-age: the overlooked metric. Can J Fish Aquat Sci 64:375-385. https://doi.org/10.1139/f07-003

Oliveira M, Pacheco M, Santos MA (2011) Fish thyroidal and stress responses in contamination monitoring - an integrated biomarker approach. Ecotoxicol Environ Saf 74:1265-1270. https://doi.org/10.1016/j.ecoenv.2011.03.001

Ostos Garrido MV, Torres MN, Equisoain MA (1993) Histological, histochemical and ultrastructural analysis of the gastric mucosa in Oncorhynchus mykiss. Aquaculture 115:121-132. https://doi.org/10.1016/0044-8486(93)90363-4

Peres H, Santos S, Oliva-Teles A (2014) Blood chemistry profile as indicator of nutritional status in European seabass (Dicentrarchus labrax). Fish Physiol Biochem 40:13391347. https://doi.org/10.1007/s10695-014-9928-5

Polakof S, Arjona FJ, Sangiao-Alvarellos S, Del Río MPM, Mancera JM, Soengas JL (2006) Food deprivation alters osmoregulatory and metabolic responses to salinity acclimation in gilthead sea bream Sparus auratus. J Comp Physiol B 176:441-452. https://doi.org/10.1007/s00360-006-0065-Z

Polakof S, Ceinos RM, Fernández-Durán B, Míguez JM, Soengas JL (2007) Daily changes in parameters of energy metabolism in brain of rainbow trout: dependence on feeding. Comp Biochem Physiol A 146:265-273. https://doi.org/10.1016/j. cbpa.2006.10.026

Pottinger TG (2010) A multivariate comparison of the stress response in three salmonid and three cyprinid species: evidence for inter-family differences. J Fish Biol 76:601-621. https://doi.org/10.1111/j.1095-8649.2009.02516.x

Pottinger TG, Rand-Weaver M, Sumpter JP (2003) Overwinter fasting and re-feeding in rainbow trout: plasma growth hormone and cortisol levels in relation to energy mobilization. Comp Biochem Physiol B 136:403-417. https://doi. org/10.1016/S1096-4959(03)00212-4

Reddy PK, Vijayan MM, Leatherland JF, Moon TW (1995) Does RU486 modify hormonal responses to handling stressor and cortisol treatment in fed and fasted rainbow trout? J Fish Biol 46:341-359. https://doi.org/10.1111/j.1095-8649.1995.tb05973.x

Rodrigues SR, Caldeira C, Castro BB, Gonçalves F, Nunes B, Antunes SC (2011) Cholinesterase (ChE) inhibition in pumpkinseed (Lepomis gibbosus) as environmental biomarker:
$\mathrm{ChE}$ characterization and potential neurotoxic effects of $\mathrm{xe}-$ nobiotics. Pestic Biochem Physiol 99:181-188. https://doi. org/10.1016/j.pestbp.2010.12.002

Sangiao-Alvarellos S, Guzmán JM, Láiz-Carrión R, Míguez JM, Martín Del Río MP, Mancera JM, Soengas JL (2005) Interactive effects of high stocking density and food deprivation on carbohydrate metabolism in several tissues of gilthead sea bream Sparus auratus. J Exp Zool A Comp Exp Biol 303:761-775. https://doi.org/10.1002/jez.a.203

Shimeno S, Shikata T, Hosokawa H, Masumoto T, Kheyyali D (1997) Metabolic response to feeding rates in common carp, Cyprinus carpio. Aquaculture 151:371-377. https:/doi. org/10.1016/S0044-8486(96)01492-5

Simonato JD, Fernandes MN, Martinez CB (2013) Physiological effects of gasoline on the freshwater fish Prochilodus lineatus (Characiformes: Prochilodontidae). Neotrop Ichthyol 11:683691. https://doi.org/10.1590/S1679-62252013000300022

Soengas JL, Strong EF, Fuentes J, Veira JAR, Andrés MD (1996) Food deprivation and refeeding in Atlantic salmon, Salmo salar: effects on brain and liver carbohydrate and ketone bodies metabolism. Fish Physiol Biochem 15:491-511. https://doi.org/10.1007/BF01874923

Straus DS, Marten NW, Hayden JM, Burke EJ (1994) Protein restriction specifically decreases the abundance of serum albumin and transthyretin nuclear transcripts in rat liver. J Nutr 124:1041-1051. https://doi.org/10.1093/jn/124.7.1041

Suarez M, Garcia-Gallego M, Trenzado C, Guil-Guerrero J, Furne M, Domezain A, Alba I, Sanz A (2014) Influence of dietary lipids and culture density on rainbow trout (Oncorhynchus mykiss) flesh composition and quality parameter. Aquac Eng 63:16-24. https://doi.org/10.1016/j.aquaeng.2014.09.001

Suchiang K, Sharma R (2011) Dietary restriction regulates brain acetylcholinesterase in female mice as a function of age. Biogerontology 12:581-589. https://doi.org/10.1007 /s10522-011-9356-1

Sumpter JP, Le Bail PY, Pickering AD, Pottinger TG, Carragher JF (1991) The effect of starvation on growth and plasma growth hormone concentrations of rainbow trout, Oncorhynchus mykiss. Gen Comp Endocr 83:94-102. https://doi. org/10.1016/0016-6480(91)90109-J

Taşbozan O, Gökçe MA, Erbaş C (2016) The effect of different growing conditions to proximate composition and fatty acid profiles of rainbow trouts (Oncorhynchus mykiss). J Appl Anim Res 44:442-445. https://doi.org/10.1080 /09712119.2015.1091323

Tocher DR (2003) Metabolism and functions of lipids and fatty acids in teleost fish. Rev Fish Sci 11:107-184. https://oi. org $/ 10.1080 / 713610925$

Torfi Mozanzadeh M, Marammazi JG, Yaghoubi M, Yavari V, Agh N, Gisbert E (2017) Somatic and physiological responses to cyclic fasting and re-feeding periods in sobaity sea bream (Sparidentex hasta, Valenciennes 1830). Aquac Nutr 23:181-191. https://doi.org/10.1111/anu.12379

Trampel D, Sell J, Ahn D, Sebranek J (2005) Preharvest feed withdrawal affects liver lipid and liver color in broiler chickens. Poultry Sci 84:137-142. https://doi.org/10.1093 $/ \mathrm{ps} / 84.1 .137$

Trinder P (1969) Determination of glucose in blood using glucose oxidase with an alternative oxygen acceptor. Ann Clin Biochem 6:24-27. https://doi.org/10.1177/000456326900600108 
Wendelaar Bonga SE (1997) The stress response in fish. Physiol Rev 77:591-625. https://doi.org/10.1152/physrev.1997.77.3.591

Yúfera M, Moyano FJ, Astola A, Pousão-Ferreira P, MartínezRodríguez G (2012) Acidic digestion in a teleost: postprandial and circadian pattern of gastric $\mathrm{pH}$, pepsin activity, and pepsinogen and proton pump mRNAs expression.
PLoS One 7:e33687. https://doi.org/10.1371/journal. pone.0033687

Zengin H, Vural N, Çelik VK (2013) Comparison of changes in fatty acid composition of starved and fed rainbow trout (Oncorhynchus mykiss) larvae. Turk J Fish Aquat Sci 13: 397-405. https://doi.org/10.4194/1303-2712-v13_3_02 